\title{
TALENT MANAGEMENT IN PRACTICE
}

An Integrated and Dynamic Approach 


\section{TALENT MANAGEMENT IN PRACTICE}

\section{An Integrated and Dynamic Approach}

BY

\section{MARIAN THUNNISSEN}

Fontys University of Applied Sciences, Eindhoven, The Netherlands

\section{EVA GALLARDO-GALLARDO}

Universitat Politècnica de Catalunya-BarcelonaTech, Barcelona, Spain

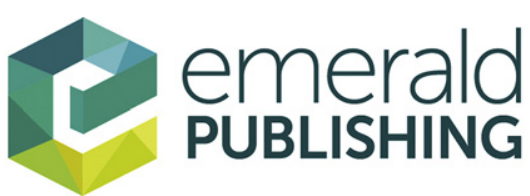

United Kingdom - North America - Japan India - Malaysia - China 
Emerald Publishing Limited

Howard House, Wagon Lane, Bingley BD16 1WA, UK

First edition 2017

Copyright (C) 2017 Emerald Publishing Limited

Reprints and permissions service

Contact: permissions@emeraldinsight.com

No part of this book may be reproduced, stored in a retrieval system, transmitted in any form or by any means electronic, mechanical, photocopying, recording or otherwise without either the prior written permission of the publisher or a licence permitting restricted copying issued in the UK by The Copyright Licensing Agency and in the USA by The Copyright Clearance Center. Any opinions expressed in the chapters are those of the authors. Whilst Emerald makes every effort to ensure the quality and accuracy of its content, Emerald makes no representation implied or otherwise, as to the chapters' suitability and application and disclaims any warranties, express or implied, to their use.

British Library Cataloguing in Publication Data

A catalogue record for this book is available from the British Library

ISBN: 978-1-78714-598-6 (Print)

ISBN: 978-1-78714-597-9 (Online)

ISBN: 978-1-78714-988-5 (Epub)

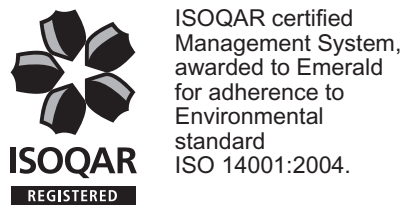

Certificate Number 1985

ISO 14001

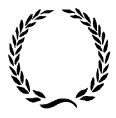

INVESTOR IN PEOPLE 


\section{ABOUT THE AUTHORS}

Marian Thunnissen works as a Professor at the school of HRM and Applied Psychology of Fontys University of Applied Sciences in Eindhoven (The Netherlands). She has over 20 years of experience in research, consulting, and teaching. Her current research is focused on the identification, attraction, and development of talent, in particular in the public sector. Her recent interests concern a "teambased" TM approach, the role of the line manager in TM, and the dilemma's and tensions organizations experience in developing and implementing TM. She finds it very important to share her knowledge with organizations and HR practitioners, in order to support them in an evidence-based TM approach.

Her work is published in Human Resource Management Review, International Journal of HRM, Personnel Review, and Employee Relations. Marian has (co-)authored several book chapters on TM, e.g., on TM in knowledge intensive organizations, TM in the public sector and TM in academia. She frequently reviews articles for academic journals such as Career Development International and Journal of Organizational Behavior. Marian is the editor-in-chief of the Dutch Journal of HRM.

Eva Gallardo-Gallardo holds a PhD and MSc in Management from the Universitat de Barcelona (UB), and two postgraduate degrees in University Teaching from the UB. 
She works as Assistant Professor of Management at the Department of Management of the School of Industrial Engineering of Barcelona (ETSEIB) at the Universitat Politècnica de Catalunya-BarcelonaTech (UPC). Prior to joining this department, she held faculty positions at the UB, and the Universitat Oberta de Catalunya (UOC). She possesses more than 14 years of teaching experience in different national and international universities in the field of management. Likewise, she has been invited to give research seminars at several international and national universities (e.g., NUI Galway, HU Applied Sciences Utrecht, Universitat de València, CUNEF, ESADE).

Her research focuses on talent management, with a particular interest in understanding the formation and evolution of the field, its dynamics, and its conceptual boundaries. Her research is published in Human Resource Management Review, Journal of World Business, International Journal of Contemporary Hospitality Management, and Employee Relations. She is referee of academic journals such as Journal of World Business, Journal of Management Inquiry, Scientometrics, European Management Review, and International Journal of Contemporary Hospitality Management.

She is member of the Editorial Board of the International Journal of Human Resource Management (IJHRM) and the Journal of Organisational Effectiveness: People and Performance (JOEPP). 


\section{FOREWORD}

For more than a decade Talent Management (TM) is a critical agenda item for senior managers (Skuza et al., 2013; Boston Consulting Group, 2014). Employers acknowledge that an engaged, skilled, and motivated workforce is the key to achieve growth and competitive advantage. Organizations are increasingly hiring TM officers and implementing TM strategies and programs to attract and retain the best employees. However, they still face difficulties to find a successful TM approach (BCG, 2014). Yet, academic research in the field of TM does not give much support in finding the right TM solutions (Al Ariss et al., 2014; Cappelli \& Keller, 2014; Collings et al., 2011). Despite the enormous expansion of research on TM, there still is a gap between theory and practice. A certain degree of ambiguity about definitions and conceptual boundaries remains, and there is little knowledge about the nature of TM in practice, the best way of implementing it, and the evolution of TM over time.

This finding was for us an important reason to write a book on TM in practice. With this book, we aim to offer an integrated and contextualized TM framework, which addresses both the nature of TM in organizations as its dynamics. We created a TM model based on lessons learned from previous academic empirical research on the one hand, and on established theoretical frameworks from related academic fields on the other hand. We hope that this book helps in building a bridge between theory and practice, and that 
the framework guides TM researchers in their future research on the TM process, and helps managers and practitioners when implementing and improving their TM approach.

The book is based on several papers we have presented at the annual meetings of the EIASM Workshop on Talent Management. We would like to thank the chairs of the workshop - David Collings, Hugh Scullion, and Vlad Vaiman and the attendants of the annual EIASM Workshop for their valuable feedback and support. 